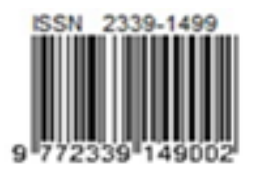

Paper ini telah direview dan dipublikasikan di Jurnal Rekayasa Sistem Industri

Volume 8 No 1 - April 2019

http://journal.unpar.ac.id/index.php/jrsi/index

ISSN 2339-1499 (online)

\title{
Efektivitas Penggunaan Instagram melalui Dua Tahap Analisis pada Zanana dan Oifyoo
}

\author{
Anastasya Maharani ${ }^{1}$, Irfan Ardiansah ${ }^{2}$, Totok Pujianto ${ }^{3}$ \\ 1,2,3) Fakultas Teknologi Industri Pertanian, Jurusan Teknologi Industri Pertanian, Universitas Padjadjaran \\ Jl. Raya Jatinangor KM 21, Jatinangor, Sumedang 45363 \\ Email: 1)anastasya14001@mail.unpad.ac.id, 2irfan@unpad.ac.id, ${ }^{3}$ totok.pujianto@unpad.ac.id
}

\begin{abstract}
The using of social media for marketing in products and services industry is currently trending, both in small and big enterprises. Zanana and Oifyoo are among the SMEs that already used Instagram to market their products. The purpose of this research is to find the effectiveness of using social media (Instagram) as online marketing on Zanana and Oifyoo. Zanana has a specified marketing team to manage their Instagram account, meanwhile Oifyoo's Instagram account is managed by the owner directly. The analysis of Instagram using effectiveness is much needed for increasing marketing, sales, or branding purposes. This research is done with a few steps including data reduction, data serving, conclusion and verification. There are two data used in this research, primary and secondary data. The primary data is accumulated using in-depth interviews and the secondary data is retrieved on both SMEs Instagram accounts. This research used media and network analyses to analyze the data. The research shows that Zanana is more excelled at the effectiveness of using Instagram in both media and network analyses than Oifyoo.
\end{abstract}

Keywords: effectiveness, Instagram, media analysis, network analysis

\begin{abstract}
Abstrak
Penggunaan media sosial dalam pemasaran suatu barang atau jasa sedang marak dilakukan oleh para pelaku usaha mulai dari usaha yang berskala kecil sampai besar. Zanana dan Oifyoo merupakan salah satu dari usaha kecil dan menengah yang sudah melakukan pemasaran produknya melalui media sosial Instagram. Tujuan dari penelitian ini adalah untuk mengetahui efektivitas penggunaan media sosial Instagram sebagai media pemasaran online pada Zanana dan Oifyoo. Zanana mempunyai tim marketing khusus untuk mengelola akun Instagram, sedangkan akun Instagram Oifyoo dikelola langsung oleh pemiliknya. Analisis efektivitas penggunaan Instagram sangat dibutuhkan guna meningkatkan usaha baik dari segi pemasaran, penjualan, ataupun branding yang disesuaikan dengan karakteristik konsumen saat ini. Tahapan penelitian yang dilakukan pada penelitian ini adalah reduksi data, penyajian data, penarikan kesimpulan, dan verifikasi. Teknik pengumpulan data dalam penelitian ini menggunakan teknik wawancara mendalam untuk data primer dan data dari laman Instagram Zanana dan Oifyoo untuk data sekunder. Analisis data yang digunakan pada penelitian ini adalah media analysis dan network analysis. Hasil penelitian ini menunjukkan bahwa Zanana lebih unggul dalam efektivitas penggunaan Instagram dari segi media analysis dan network analysis dibandingkan dengan Oifyoo.
\end{abstract}

Kata kunci: efektivitas, Instagram, media analysis, network analysis

\section{Pendahuluan}

Usaha Kecil dan Menengah merupakan salah satu poros penting dalam pertumbuhan ekonomi di negara-negara kawasan Asia, termasuk Indonesia (Sun, 2004). Di Indonesia, pemerintah mendorong para pelaku usaha kecil dan menengah untuk meningkatkan daya saing mereka dalam menghadapi pasar global Kota
Bandung merupakan salah satu kota yang mendorong tumbuhnya UKM guna menyejahterakan kehidupan warganya, Menurut Rusdin, Suryanto dan Muttaqin (2015), sektor industri makanan dan minuman menempati posisi pertama industri yang paling banyak di Kota Bandung, dengan jumlah 13.353 unit usaha. 
Pemasaran dan penjualan yang dilakukan oleh sebagian besar UKM makanan dan minuman di kota Bandung tidak menggunakan perantara (direct selling), karena biaya distribusi mahal dan kapasitas yang dimiliki masih rendah. Maka dari itu banyak UKM yang menggunakan media sosial untuk mempromosikan produknya (Hubeis, 2015). Pemasaran secara online banyak dilakukan oleh para pelaku usaha karena dapat menyesuaikan dengan karakteristik konsumen yang lebih memilih untuk membeli segala sesuatu yang sesuai dengan pendapatan yang dimiliki para konsumen, dan juga konsumen dapat berbelanja dengan mudah, hemat, dan efisien (Saputri, 2016).

Menurut Purwidiantoro (2016), Instagram dan Facebook merupakan media sosial yang paling banyak digunakan oleh UKM. Media sosial tersebut banyak dimanfaatkan oleh para pelaku usaha untuk membagikan konten promosi produknya untuk menjaring konsumen dan juga digunakan untuk membangun komunikasi dengan pelanggan maupun dengan calon konsumen. Penggunaan Instagram lebih unggul jika dibandingkan dengan Facebook karena mampu menjangkau pasar anak muda usia produktif dan juga memiliki fitur yang lebih mudah untuk digunakan dan menguntungkan para pelaku usaha.

Meskipun banyak UKM yang telah melakukan pemasaran produknya secara online melalui media sosial, masih terdapat beberapa kendala yang dihadapi oleh UKM, seperti misalnya penguasaan teknologi yang masih kurang dan kemampuan melakukan pemasaran yang rendah (Ardianto, Kastaman dan Ardiansah, 2017). Maka dari itu, terdapat UKM yang memiliki tim untuk melakukan social media marketing, ada juga UKM yang melakukan atau mengelola social media marketing-nya sendiri. Zanana dan Oifyoo merupakan UKM yang sudah berkembang dengan pesat, keduanya sama-sama terletak di Kota Bandung dan bergerak di sektor industri makanan dan minuman. Keduanya memiliki akun Instagram yang jumlah pengikutnya cukup banyak, sama-sama diatas 30.000 pengikut, dan terus bertambah setiap harinya. Zanana memiliki produk keripik pisang dengan berbagai varian rasa yang disesuaikan dengan selera anak muda yang dibungkus dengan kemasan yang menarik. Zanana sudah memiliki struktur organisasi yang jelas. Pemasaran online produk Zanana sangat teratur karena memang dipegang oleh tim yang ahli dalam hal social media marketing, sehingga setiap aktivitasnya teratur dan terjadwal dengan baik. Sedangkan Oifyoo merupakan usaha yang bisa terbilang cukup sederhana namun memiliki pasar yang cukup luas dan memiliki produk-produk olahan dari keju mozzarella. Oifyoo belum memiliki struktur organisasi yang jelas, hampir sebagian besar pekerjaan dikerjakan oleh pemilik usahanya langsung. Semua kegiatan pemasaran Oifyoo dilakukan sendiri oleh pemilik usaha langsung, baik online maupun offline.

Ada beberapa metode analisis penting yang harus diperhatikan dalam mengelola akun Instagram untuk pemasaran produk, diantaranya adalah media analysis dan network analysis. Media analysis terdiri dari reach analysis, engagement analysis, dan virality analysis. Sedangkan network analysis terdiri dari dynamic network dan influencer identification (Sutanto, 2017).

Berdasarkan uraian diatas, perlu diadakan penelitian untuk menganalisa efektivitas penggunaan Instagram pada UKM Oifyoo dan Zanana. Kedua UKM tersebut memiliki perbedaan dalam mengelola pemasaran dengan menggunakan media sosialnya, dimana Zanana telah memiliki tim khusus untuk social media marketing, dan Oifyoo belum memiliki tim khusus untuk social media marketing, semua media sosial masih dikelola sendiri oleh pemilik usahanya.

\section{Metode Penelitian}

Penelitian ini dilaksanakan di Zanana dan Oifyoo, dimana kedua UKM berlokasi di Kota Bandung. Zanana memiliki produk cemilan keripik pisang dan Oifyoo memiliki banyak produk olahan keju mozzarella. Data primer pada penelitian ini diperoleh melalui proses wawancara mendalam kepada kepala tim marketing Zanana dan pemilik Oifyoo, sedangkan data sekunder diperoleh melalui laman profil Instagram Zanana (@zananachips) dan Oifyoo (@oifyoo).

Teknik analisis data dalam penelitian ini dilaksanakan melalui beberapa tahapan, yaitu reduksi data, penyajian data, penarikan kesimpulan, dan verifikasi (Miles dan Huberman, 2014). Ada dua tahap analisis yang akan digunakan untuk menganalisa efektivitas penggunaan Instagram, yang pertama adalah media analysis yang terdiri dari tiga matriks, 
yaitu reach, engagement, dan virality. Hasil wawancara kedua usaha tersebut nantinya akan dilihat keefektivitasannya melalui teori benchmarking. Kemudian yang kedua adalah network analysis yang terdiri dari influencer identification dan dynamic network.

\section{Hasil dan Pembahasan}

Zanana dan Oifyoo merupakan dua UKM di Kota Bandung yang bergerak di sektor industri makanan dan minuman yang memilikki beberapa kesamaan, diantaranya adalah memiliki akun Instagram dengan jumlah pengikut yang cukup banyak, yaitu diatas 20.000 pengikut, yang terus bertambah setiap harinya. Selain itu, Zanana dan Oifyoo memiliki target pasar yang sama, yaitu anak muda dan orang dewasa yang berusia berkisar 18-34 tahun. Zanana dan Oifyoo pun sama-sama mulai menggunakan Instagram untuk memasarkan produknya mulai tahun 2013. Dalam menjalankan social media marketing, Zanana memiliki tim marketing sendiri sehingga semua aktifitas pemasarannya dapat dikelola dengan baik dan berjalan dengan teratur, berbeda dengan Oifyoo yang aktifitas pemasarannya hanya dikelola oleh pemilik usahanya saja.

Berdasarkan hasil wawancara mendalam terhadap narasumber yang telah ditentukan, diperoleh hasil sebagai berikut:

\section{Media Analysis}

Media analysis merupakan tahapan pertama untuk analisa efektivitas penggunaan media sosial Instagram Zanana dan Oifyoo. Tahapan ini dilakukan untuk mengukur kinerja akun Instagram. Dalam tahapan ini terdapat tiga matriks, yaitu reach, engagement, dan virality.

\section{Reach Analysis}

Digunakan untuk mengetahui seberapa besar jangkauan yang mampu diraih oleh Instagram Oifyoo maupun Zanana. Jangkauan tersebut dapat dilihat melalui data total pengikut dari akun Instagram UKM yang bersangkutan melalui fitur Instagram Insight yang terdapat pada profil bisnis Instagram. Data tersebut dapat berupa data jenis kelamin, usia, dan demografi responden. Berdasarkan hasil wawancara mendalam terhadap narasumber dari Zanana dan Oifyoo, diperoleh hasil reach analysis yang dapat dilihat pada Tabel 1 .
Tabel 1. Hasil wawancara - reach analysis

\begin{tabular}{|c|c|c|}
\hline Pertanyaan & Zanana & Oifyoo \\
\hline $\begin{array}{l}\text { Mengetahui } \\
\text { fitur business } \\
\text { profile di } \\
\text { Instagram? }\end{array}$ & Ya & Ya \\
\hline $\begin{array}{l}\text { Mengetahui } \\
\text { adanya tools di } \\
\text { Instagram } \\
\text { untuk mendata } \\
\text { engagement } \\
\text { akun Instagram }\end{array}$ & Ya & $\mathrm{Ya}$ \\
\hline $\begin{array}{l}\text { Menggunakan } \\
\text { aplikasi lain } \\
\text { untuk } \\
\text { menganalisa } \\
\text { engagement } \\
\text { akun Instagram }\end{array}$ & $\mathrm{Ya}$ & Tidak \\
\hline $\begin{array}{c}\text { Seberapa } \\
\text { sering } \\
\text { memperhatikan } \\
\text { insights akun } \\
\text { Instagram }\end{array}$ & Jarang & Sering \\
\hline $\begin{array}{c}\text { Top location } \\
\text { dari pengikut } \\
\text { akun Instagram }\end{array}$ & $\begin{array}{l}\text { Jakarta \& } \\
\text { Bandung }\end{array}$ & $\begin{array}{l}\text { Jakarta \& } \\
\text { Bandung }\end{array}$ \\
\hline $\begin{array}{l}\text { Rentang usia } \\
\text { dari pengikut } \\
\text { akun Instagram }\end{array}$ & $\begin{array}{c}18-35 \\
\text { tahun }\end{array}$ & $\begin{array}{c}18-35 \\
\text { tahun }\end{array}$ \\
\hline $\begin{array}{l}\text { Jenis kelamin } \\
\text { mayoritas dari } \\
\text { pengikut akun } \\
\text { Instagram }\end{array}$ & Perempuan & Perempuan \\
\hline $\begin{array}{c}\text { Pada jam } \\
\text { berapa dan hari } \\
\text { apa saja } \\
\text { pengikut akun } \\
\text { Instagram aktif }\end{array}$ & $\begin{array}{l}\text { Jam-jam } \\
\text { istirahat, } \\
\text { setiap hari }\end{array}$ & $\begin{array}{c}\text { Jam 1, } \\
\text { setiap hari }\end{array}$ \\
\hline $\begin{array}{l}\text { Hasil analisis } \\
\text { fitur insights } \\
\text { mempengaruhi } \\
\text { bagaimana } \\
\text { mengelola akun } \\
\text { Instagram }\end{array}$ & $\begin{array}{c}\text { Tidak } \\
\text { terlalu, } \\
\text { namun bisa } \\
\text { dijadikan } \\
\text { acuan }\end{array}$ & Tidak \\
\hline $\begin{array}{c}\text { Ada waktu } \\
\text { tertentu untuk } \\
\text { mengunggah } \\
\text { konten }\end{array}$ & Tidak & Tidak \\
\hline $\begin{array}{c}\text { Apakah } \\
\text { pencapaian } \\
\text { sekarang sudah } \\
\text { sesuai dengan } \\
\text { target pasar } \\
\end{array}$ & Ya & $\mathrm{Ya}$ \\
\hline
\end{tabular}

Berdasarkan hasil wawancara, Zanana dan Oifyoo mengetahui adanya fitur business profile dan insight di Instagram, dan keduanya telah mengaktifkan fitur tersebut. Akan tetapi, Zanana jarang memperhatikan hasil analisa akun Instagramnya dari fitur insight, karena tim marketing Zanana lebih memilih menggunakan aplikasi lain untuk menganalisa akun 
Instagramnya, yaitu Iconosquare dan Google Analytics karena hasilnya lebih akurat. Berbeda dengan Zanana, Oifyoo lebih sering memperhatikan insight akun Instagramnya, dan tidak menggunakan aplikasi lain untuk menganalisa aktifitas akun Instagramnya. Adapun hasil analisa fitur insight tidak mempengaruhi kedua UKM dalam mengelola akun Instagramnya, hanya saja terkadang dijadikan acuan, contohnya adalah Zanana dan Oifyoo tidak memiliki jadwal atau waktu khusus untuk menggunggah konten di Instagram, pengunggahan konten dilakukan secara eksperimental dan fleksibel dan mengacu kepada hasil insights yang bisa menunjukkan jam aktif para pengikut Instagram. Adapun pengikut Instagram Zanana dan Oifyoo banyak berasal dari Jakarta dan Bandung, dan juga memiliki rentang usia pengikut Instagram yang sama, yaitu 18-35 tahun, dan kebanyakan dari pengikutnya berjenis kelamin perempuan.

\section{Engagement Analysis}

Digunakan untuk mengetahui aktivitas dalam membuat isi konten Instagram UKM yang bersangkutan serta mengetahui feedback yang didapatkan dari konsumen, dimana feedback tersebut dapat berupa komentar ataupun pesan pribadi (direct messages). Hasil wawancara mendalam engagement analysis terhadap narasumber dari Zanana dan Oifyoo dapat dilihat pada Tabel 2.

Tabel 2. Hasil wawancara - engagement analysis

\begin{tabular}{|c|c|c|}
\hline Pertanyaan & Zanana & Oifyoo \\
\hline $\begin{array}{c}\text { Cara untuk } \\
\text { mempertahank } \\
\text { an } \\
\text { engagement } \\
\text { rate }\end{array}$ & $\begin{array}{l}\text { Melakukan } \\
\text { endorse, } \\
\text { giveaway, } \\
\text { dan } \\
\text { memasang } \\
\text { iklan }\end{array}$ & $\begin{array}{l}\text { Mengungg } \\
\text { ah foto } \\
\text { yang } \\
\text { menarik, } \\
\text { memasang } \\
\text { iklan }\end{array}$ \\
\hline $\begin{array}{c}\text { Fitur yang } \\
\text { sering } \\
\text { digunakan } \\
\text { untuk } \\
\text { meningkatkan } \\
\text { atau } \\
\text { mempertahank } \\
\text { an } \\
\text { engagement } \\
\text { rate }\end{array}$ & $\begin{array}{l}\text { Instastory, } \\
\text { sedang } \\
\text { bereksperim } \\
\text { en } \\
\text { menggunak } \\
\text { an IGTV }\end{array}$ & Instastory \\
\hline $\begin{array}{c}\text { Apakah } \\
\text { memiliki } \\
\text { standar } \\
\text { khusus untuk } \\
\text { tahu bahwa } \\
\text { engagement } \\
\text { rate sudah } \\
\text { bagus }\end{array}$ & $\mathrm{Ya}$ & Tidak \\
\hline
\end{tabular}

Tabel 3. Hasil wawancara - engagement analysis (lanjutan)

\begin{tabular}{|c|c|c|}
\hline $\begin{array}{c}\text { Berapa banyak } \\
\text { feedback yang } \\
\text { berhasil diraih } \\
\text { ketika akun } \\
\text { Instagram } \\
\text { mengunggah } \\
\text { foto/video/story }\end{array}$ & $\begin{array}{c}\text { Kurang } \\
\text { lebih } 300 \\
\text { akun }\end{array}$ & $\begin{array}{c}\text { Kurang } \\
\text { lebih } 100 \\
\text { akun }\end{array}$ \\
\hline $\begin{array}{c}\text { Sering } \\
\text { menerima kritik } \\
\text { dan saran dari } \\
\text { konsumen } \\
\text { melalui } \\
\text { Instagram }\end{array}$ & $\mathrm{Ya}$ & $\mathrm{Ya}$ \\
\hline
\end{tabular}

Berdasarkan hasil wawancara, Zanana dan Oifyoo memiliki cara yang berbeda dalam mengelelola dan mempertahankan engagement rate akun Instagramnya. Cara mempertahankan engagement rate akun Instagram Zanana adalah dengan cara fokus melakukan kegiatan pemasaran, contohnya dengan endorse influencer, memasang iklan di Instagram, mengadakan giveaway, membuka peluang bagi reseller karena banyak orang tertarik untuk menjual kembali produknya. Fitur Instagram yang sering digunakan Zanana untuk mempertahankan engagement rate adalah Instagram Story, dimana terdapat banyak fiturfitur lain yang menarik seperti polling, $Q \& A$, stiker-stiker yang menarik, dan masih banyak lagi. Selain itu, Zanana juga sedang bereksperimen untuk membuat konten menarik di IGTV-nya guna meningkatkan engagement rate akun Instagramnya. Tim marketing Zanana memiliki standar khusus yang menandakan bahwa engagement rate akun Instagramnya sudah baik, yaitu dengan mendapatkan tanda telah dilihat atau tanda suka (like) sejumlah $1 \%$ dari jumlah pengikut akun Instagramnya pada setiap konten yang diunggah. Adapun jumlah feedback yang diperoleh akun Instagram Zanana ketika mengunggah foto atau video kurang lebih mendapatkan tanda suka (like) dari 300 akun, dimana jumlah tersebut sudah memenuhi standar khusus tim marketing Zanana. Kritik dan saran mengenai produknya pernah didapatkan oleh Zanana melalui akun Instagram, dan Zanana sangat mengapresiasi pengikut akun Instagramnya yang tidak segan untuk melakukan hal tersebut, selain itu Zanana juga terinspirasi untuk membuat kampanye tentang keberanian untuk komplain produk bagi para pengikut akun Instagramnya. 
Berbeda dengan Zanana, Oifyoo memiliki cara sendiri dalam mempertahankan engagement rate akun Instagramnya, yaitu dengan cara mengunggah foto atau videonya yang menarik dan juga memasang iklan di Instagram. Oifyoo sendiri memang memiliki banyak produk olahan keju mozzarella yang unik dan harganya terjangkau, maka dari itu Oifyoo lebih mengandalkan foto atau video produknya dalam menjaring konsumen di Instagram. Fitur di Instagram yang sering dipakai untuk mempertahankan engagement rate adalah Instagram Story. Oifyoo sendiri tidak memiliki standar khusus yang menandakan bahwa engagement rate akun Instagramnya sudah baik, bagi Oifyoo yang terpenting adalah jumlah pengikutnya tidak berkurang. Dalam satu kali mengunggah foto atau video, jumlah tanda suka (like) yang didapatkan akun Instagram Oifyoo tidak menentu, tergantung menarik atau tidaknya foto atau video produk yang diunggah, namun narasumber dari pihak Oifyoo mengatakan bahwa kurang lebih mendapatkan tanda suka (like) dari sekitar 100 akun pada setiap unggahannya. Oifyoo sendiri jarang menerima kritik dan saran mengenai produknya melalui Instagram, akan tetapi banyak pengikut akun Instagramnya yang memberikan kritik dan saran mengenai pelayanan admin karena tergolong lamban dalam merespon atau melayani konsumennya di Instagram. Pelayanan yang kurang cepat dari admin akun Instagram Oifyoo disebabkan masih dikelolanya akun Instagram oleh pemilik usahanya sendiri.

\section{Virality Analysis}

Digunakan untuk mengetahui seberapa banyak pengikut akun Instagram UKM yang bersangkutan ataupun pengguna Instagram yang menggunakan tagar (\#) yang bersangkutan dengan kedua UKM terkait. Memasarkan produk dari suatu usaha harus menggunakan strategi pemasaran yang baik, salah satu caranya adalah dengan melakukan strategi viral marketing, agar produk dapat dijangkau dan dikenal oleh konsumen melalui akses internet. Selain itu, viral marketing juga dapat meningkatkan kepercayaan konsumen terhadap suatu merek atau produk. Hasil wawancara mendalam mengenai virality analysis dapat dilihat pada Tabel 3 .
Tabel 4. Hasil wawancara - virality analysis

\begin{tabular}{|c|c|c|}
\hline Pertanyaan & Zanana & Oifyoo \\
\hline $\begin{array}{c}\text { Apakah ada } \\
\text { slogan atau ciri } \\
\text { khas yang bisa } \\
\text { dipakai oleh } \\
\text { banyak orang }\end{array}$ & Ya & Ya \\
\hline $\begin{array}{c}\text { Apakah dengan } \\
\text { adanya slogan } \\
\text { atau ciri khas } \\
\text { dapat membantu } \\
\text { pemasaran } \\
\text { produk }\end{array}$ & Ya & Ya \\
\hline $\begin{array}{c}\text { Memiliki strategi } \\
\text { untuk membuat } \\
\text { konten yang unik }\end{array}$ & Ya, akan & dibuat \\
\hline $\begin{array}{c}\text { Pernah } \\
\text { mengadakan } \\
\text { giveaway }\end{array}$ & Ya & Tidak \\
\hline
\end{tabular}

Zanana memiliki slogan atau ciri khas khusus di Instagram dalam bentuk tagar \#senangnyabisadibagi, alasan dibalik dibuatnya slogan tersebut adalah Zanana ingin membuat suatu kampanye di media sosial yang bersifat general atau umum, dimana slogan tersebut bisa digunakan oleh banyak orang dan dapat membuat orang teringat akan produk Zanana. Selain tagar \#senangnyabisadibagi, Zanana sering membuat tagar lain yang mampu menarik konsumen untuk ikut menggunakannya, contohnya tagar \#ZananaChips dan \#senangnyabisatravellingbarengZanana. Efek dari adanya tagar tersebut dalam pemasaran produknya di Instagram tidak terasa secara langsung, namun dengan adanya tagar tersebut, Zanana jadi lebih mudah dalam melakukan branding. Zanana memiliki rencana kedepannya untuk membuatu suatu konten unik untuk dijadikan bahan viral marketing, sekarang ini Zanana sedang mencari referensi konten seperti apa yang harus dibuat dan konten apa yang sedang viral. Salah satu usaha Zanana dalam melakukan viral marketing adalah dengan mengadakan gievaway produkproduknya dan bingkisan khas Zanana, adapun pelaksanaan giveaway biasanya memang sudah direncanakan dan rutin pada saat-saat tertentu, seperti lebaran, ulang tahun Zanana, dan kolaborasi dengan influencer.

Oifyoo juga memiliki tagar yang bisa digunakan oleh banyak orang di Instagram, yaitu \#oifyoo. Dengan adanya tagar \#oifyoo, pemilik usaha merasa sangat terbantu dalam 
pemasaran produknya dan juga branding usahanya. Berbeda dengan Zanana, Oifyoo tidak memiliki rencana kedepannya untuk melakukan viral marketing dengan cara membuat konten unik. Pihak Oifyoo pusat belum pernah mengadakan giveaway, namun agen-agen dari Oifyoo di beberapa daerah di luar Kota Bandung pernah mengadakan giveaway produk-produk Oifyoo.

\section{Network Analysis}

Network analysis perlu dilakukan untuk mengetahui sejauh mana keberhasilan akun Instagram Zanana dan Oifyoo yang dipengaruhi oleh influencer di media sosial. Network analyis terdiri dari influencer identification dan dynamic network. Influencer identification bertujuan untuk mengetahui siapa orang yang memiliki tingkat influence yang tinggi sehingga dapat mempengaruhi kemajuan dan perkembangan dari UKM Oifyoo dan Zanana. Hasil wawancara mengenai network analysis dapat dilihat pada Tabel 4.

Tabel 5. Hasil wawancara - network analysis

\begin{tabular}{|c|c|c|}
\hline $\begin{array}{c}\text { Pertanyaan } \\
\text { ambassadiki brand } \\
\text { mempromosikan } \\
\text { produk }\end{array}$ & Zanana & Oifyoo \\
\hline $\begin{array}{c}\text { Adanya brand } \\
\text { ambassador } \\
\text { penting }\end{array}$ & $\mathrm{Ya}$ & Tidak \\
\hline $\begin{array}{c}\text { Adanya } \\
\text { influencer atau } \\
\text { brand } \\
\text { ambassador } \\
\text { sangat membantu } \\
\text { promosi dan } \\
\text { penjualan produk }\end{array}$ & $\mathrm{Ya}$ & $\mathrm{Ya}$ \\
\hline $\begin{array}{c}\text { Pernah } \\
\text { mengadakan } \\
\text { kerjasama dengan } \\
\text { UKM lain }\end{array}$ & $\mathrm{Ya}$ & Tidak \\
\hline
\end{tabular}

Berdasarkan hasil wawancara, Zanana dan Oifyoo diketahui tidak memiliki brand ambassador, Zanana memiliki alasan kuat mengapa memilih untuk tidak memilikinya, yaitu ketika memilih seseorang untuk dijadikan brand ambassador, hal itu terlalu berat, karena sepositif apapun orang itu, pasti akan ada masa naik-turun dalam kesehariannya, pihak Zanana takut akan terkena dampak dari masa naikturun tersebut. Maka dari itu, Zanana lebih memilih untuk melakukan endorse terhadap influencers, dimana influencer yang akan diajak bekerja sama pun diseleksi oleh tim marketing karena ada beberapa kriteria tertentu yang ditetapkan seperti misalnya jumlah pengikut akun Instagramnya, budget endorse, dan lainnya. Beberapa influencers yang pernah bekerja sama dengan Zanana adalah Citra Kirana, Gita Savitri, Cut Syifa, dan Anissa Aziza. Adanya influencer yang mempromosikan produk Zanana sangat berpengaruh terhadap peningkatan jumlah pengikut akun Instagram Zanana, selain itu feedback yang didapatkan dari pengikut akun Instagram pun meningkat pesat, bisa mencapai ribuan. Dalam menjalin kerjasama dan hubungan baik dengan sesama produk lokal, Zanana telah beberapa kali mengadakan kolaborasi dengan UKM lain, seperti kerja sama dengan Esgotado berupa tas yang bermotif pisang Zanana, kemudian juga pernah kerja sama dengan Woodka berupa jam tangan dengan motif pisang Zanana, dan kedepannya juga Zanana akan mengadakan kerja sama dengan Niion yang juga merupakan produsen tas yang sudah cukup terkenal di Kota Bandung dan sekitarnya.

Dari proses wawancara dengan narasumber dari Oifyoo, diketahui bahwa Oifyoo belum pernah melakukan endorse terhadap siapapun, namun agen Oifyoo di luar Bandung pernah melakukan endorse terhadap seorang model di daerahnya. Pihak Oifyoo pusat masih melakukan pemasaran produknya secara sederhana, dan masih belum terlalu fokus dalam mengembangkan dan mengelola Instagramnya.

\section{Kesimpulan dan Saran}

\section{Kesimpulan}

Melalui dua tahapan analisis yang dapat digunakan untuk melihat efektivitas penggunaan media sosial Instagram sebagai media pemasaran pada Zanana dan Oifyoo. Tahap pertama adalah media analysis, pada tahapan ini terlihat keefektivitasan penggunaan Instagram melalui teori benchmarking yang diaplikasikan pada 3 matriks yaitu reach, engagement, dan virality. Jangkauan pemasaran Zanana dan Oifyoo melalui Instagram dapat dikatakan sudah efektif karena sesuai dengan target pasar yang dituju. Zanana dan Oifyoo sama-sama memiliki jumlah pengikut diatas 30.000 akun, dan mayoritas pengikutnya adalah perempuan, dan mayoritas 
usia pengikut akun Instagramnya adalah pada rentang 18-35 tahun. Penggunaan hashtag atau tagar dan isi konten Instagram kedua usaha tersebut secara umum sudah diperhatikan karena secara efektif mempengaruhi respon dari konsumen dan calon konsumen. Namun dalam hal engagement analysis dan virality analysis, Zanana terlihat lebih unggul karena dari hasil wawancara, Zanana lebih terorganisir dan teratur dalam mengelola akun Instagramnya, serta mempersiapkan rencana kedepannya mengenai pengelolaan akun Instagramnya. Sedangkan Oifyoo masih memiliki kekurangan pada matriks engagement dan virality, seperti misalnya pelayanan terhadap konsumen di Instagram yang masih kurang maksimal, dan belum pernahnya melakukan kerja sama seperti endorse dengan influencer.

Network analysis merupakan tahapan analisis kedua yang dilakukan guna mengetahui sejauh mana keberhasilan influencer yang diajak bekerja sama oleh Zanana dan Oifyoo. Zanana pernah mengajak cukup banyak artis dan influencer untuk mempromosikan produknya, seperti Gita Savitri, Annisa Aziza, dan masih banyak lagi. Konsumen-konsumen yang merekomendasikan produk-produk Zanana atau Oifyoo melalui unggahan pada akun Instagram pribadinya juga dapat disebut influencer. Adanya influencer yang mempromosikan produk Zanana sangat berpengaruh terhadap bertambahnya jumlah pengikut akun Instagram Zanana, selain itu membuat Zanana dapat dikenal lebih banyak orang, atau bahkan meningkatkan penjualan produk. Selain itu Zanana juga pernah berkolaborasi dengan produk-produk lokal lainnya seperti Esgotado dan Woodka. Berbeda dengan Zanana, Oifyoo belum pernah mengadakan kerja sama endorse dengan siapapun dan belum pernah berkolaborasi dengan siapapun.

\section{Saran}

Penggunaan media sosial harus diperhatikan oleh para pelaku usaha guna meningkatkan penjualan ataupun awareness konsumen terhadap produk yang dijual, maka dari itu hasil penelitian ini diharapkan dapat menjadi acuan bagi para pelaku usaha dalam mengelola media sosial milik usahanya.

\section{Daftar Pustaka}

Ardianto, R., Kastaman, R. and Ardiansah, I. (2017) 'Design of Competitiveness Index Software of Food Small Medium Enterprises (SMEs) With Diamond Porter Model Adaptation', Journal of Industrial and Information Technology in Agriculture, 1(2), pp. 53-63.

Miles, M. B. and Huberman, M. A. (2014) Analisis Data Kualitatif. Jakarta: Universitas Indonesia.

Purwidiantoro, M. H. (2016) 'Pengaruh Penggunaan Media Sosial Terhadap Pengembangan Usaha Kecil Menengah (UKM)', EKA CIDA, 1.

Rusdin, Suryanto and Muttaqin, Z. (2015) 'Model Pemberdayaan Usaha Mikro, Kecil Dan Menengah (UMKM) Berbasis Kolaborasi', pp. 1-32.

Saputri, M. E. (2016) 'Pengaruh Perilaku Konsumen terhadap Pembelian Online Produk Fashion pada Zalora Indonesia', Jurnal Sosioteknologi, 15.

Sun, T. (2004) Knowledge Required to Achieve Entrepreneurial Success. University of Phoenix.

Sutanto, H. (2017) 'Efektivitas Penggunaan Instagram melalui Tiga Tahap Analisis pada Bebini Gelati Cafe', AGORA, 5. 
Halaman ini sengaja dikosongkan This page is intentionally left blank 